https://nv.nltu.edu.ua

https://doi.org/10.36930/40300312

Article received 02.06.2020 p.

Article accepted 04.06.2020 p.

\title{
ВОДОГОСПОДАРСЬКА РЕКУЛЬТИВАЦІЯ ПОРУШЕНИХ ДОБУВАННЯМ БУРОГО ВУГІЛЛЯ ЗЕМЕЛЬ НІМЕЧЧИНИ
}

\begin{abstract}
Гірничодобувна діяльність людини відкритим способом істотно змінює ландшафт. Рекультивація післягірничих територій є обов'язком гірничодобувних підприємств та закріплена у кожній країні на законодавчому рівні. Функції ландшафту повинні бути відновленими для підтримання природного балансу та наступного господарського користування. Для цього потрібне встановлення нових біогеоценотичних зв'язків на усіх рівнях. На екологічному рівні це означає заселення кар'єрів і відвалів видами рослин і тварин, а на економічному - інтеграцію колишніх гірничих відводів із добування бурого вугілля відкритим способом у локальні та регіональні бізнес-мережі. Одночасно потрібно реорганізовувати і розвивати соціальні та культурні функції. Здійснено порівняння видобування бурого вугілля поверхневим способом у трьох великих буровугільних родовищах Німеччини за основними критеріями. Проаналізовано проект рекультивації "Центральнонімецький озерний пейзаж", яким передбачалося використання для відтворення порушеної території основних озер, річок, каналів та шлюзів. Наведено зв'язок між закриттям буровугільних кар'єрів, припиненням відкачування грунтових вод та наступним водопідйомом, як сприятливим чинником для створення великих штучних водойм. Проаналізовано раціональність використання рудникових вод із діючих буровугільних кар'єрів для забезпечення швидкого затоплення котлованів придатною для купання водою. Застосування останні двадцять років цієї практики розглядають, як зв'язок між діючим вуглевидобутком та рекультивацією для досягнення найкращих результатів. Показано місце новоутворених кар'єрних озер у системі найбільших озер Німеччини із зазначенням спектра їх використання для дозвілля і відпочинку, охорони природи та ландшафту. Визначено екологічні ризики під час водогосподарської рекультивації післягірничих ландшафтів. Це $є$ питання усунення наслідків підняття грунтових вод, недостатнього обслуговування водойм, потреби регулярного протиповіневого захисту, неналежної якості води через надходження заліза та його окислення, реорганізації тимчасових водойм та геотехнічної безпеки бортів кар'єрів і схилів відвалів. Відзначено складні завдання водогосподарської рекультивації, які ще потребують вирішення для забезпечення екологічної рівноваги.
\end{abstract}

Ключові слова: буровугільне родовище; гірнича діяльність; відтворення; ландшафт; кар'єр; лігніт; штучна водойма.

\section{Вступ}

Поклади бурого вугілля в Німеччині сформувалися в третинному періоді близько 65-2 млн років тому. На території країни виявлені великі запаси кам'яного вугілля, в т.ч. у відкладах верхнього карбону. Провідне значення має Нижньорейнсько-Вестфальський (Рурський) вугільний басейн. У цьому басейні вугільні пласти мають в основному круте падіння, часто сильно тектонічно порушені, залягають на великій глибині, водо- і газонасичені. Родовища бурого вугілля зосереджені в Нижньорейнському, Нідерлаузіцькому (Котбус і Дрезден), Середньонімецькому (Галле і Лейпціг), Магдебурзькому та ін. басейнах. Вугілля в Лаузіц та Рейнланд утворилося в міоцені (5-25 млн років тому), а навколо Гельмстеда і Лейпцига - 50-60 млн років тому. Пласти бурого вугілля потужністю 3-4, 4-12, 8-14, 8-12 м приурочені до відкладів середнього еоцену - серреднього міоцену. Теплотворна здатність рядового бурого вугілля 7,3-10,0 МДж/кг, зольність 10-30\%. За умови постійного виробництва (176,3 млн т у 2006 р.) запасів бурого вугілля у Німеччині вистачило б на 231 рік [5].
Промисловий видобуток, переробка та виробництво електроенергії із бурого вугілля у Німеччині відбувається понад 100 років [1, 4, 6, 12]. У Центральній та Східній Німеччині ця галузь промисловості довгий час була основою динамічного економічного розвитку $[1,2$, $3,6,7,8,9,10,11]$. НДР орієнтувала своє виробництво енергії на велику кількість бурого вугілля через брак іншої сировини. Гірничодобувні роботи здійснювали із високою продуктивністю у складних метеорологічних умовах зимового періоду. Видобуток і переробка цієї сировини ставали складнішими з огляду на посилання економічних проблем. До припинення існування НДР у 1989 р. виникла велика кількість порушених земель. Після возз'єднання Німеччини у 1990 р. розроблено програму відтворення ландшафтів після добування бурого вугілля, необхідною умовою якої було довгострокове забезпечення державними коштами $[2,6,7,8,9$, $10,11]$.

Федеральні землі Бранденбург, Саксонія, СаксоніяАнгальт та Тюрингія домовилися про спільне провадження, фінансування та організацію рекультивації від-

\section{Інформація про автора:}

Башуцька Уляна Богданівна, канд. с.-г. наук, доцент, кафедра екології. Email: ecology@nltu.edu.ua; https://orcid.org/0000-0002-4131-014X

Цитування за ДСтУ: Башуцька У. Б. Водогосподарська рекультивація порушених добуванням бурого вугілля земель Німеччини. Науковий вісник НЛтУ України. 2020, т. 30, № 3. С. 66-70.

Citation APA: Bashutska, U. В. (2020). Water reclamation of lands of Germany disturbed by lignite mining. Scientific Bulletin of UNFU, 30(3), 66-70. https://doi.org/10.36930/40300312 
працьованих буровугільних родовищ, уклавши "Адміністративну угоду про регулювання фінансування екологічно забруднених територій". Це забезпечило здійснення найбільшого обсягу рекультиваційних робіт в Європі $[4,6,7,8,9,11,12]$. Колишні буровугільні розробки відкритого типу стають привабливими ландшафтами, покращуючи економічний потенціал регіону. Адміністративна угода зазнавала змін через виникнення нових проблем (природне підняття рівня грунтових вод). Спільні зусилля із відтворення порушених земель описуються як історія успіху німецької єдності [6].

Порушені землі, загальною площею понад 100000 га, перетворені на економічно перспективні території або природоохоронні зони. Великі озера, створені у колишніх буровугільних котлованах, надають ландшафтам на півдні Лейпцига, поблизу Біттерфельда та в Лаузіці нового значення. Незважаючи на незавершеність проектів із рекультивації, результати їх застосування для дозвілля та відпочинку є позитивними. Створені сучасні індустріальні парки (фотоелектричні та вітроенергетичні компанії) забезпечили робочі місця [6]. Отже, завдання систематизації технічного, технологічного і наукового досвіду водогосподарської рекультивації гірничих кар'єрів $\epsilon$ актуальним і має важливе наукове й прикладне значення для відтворення техногенних комплексів України.

Актуальність дослідження полягає у розширенні знань стосовно можливостей відтворення післягірничих ландшафтів шляхом створення штучних водойм у котлованах буровугільних кар'єрів для оптимального планування рекультиваційних заходів.

Об'єкт дослідження - новоутворені штучні озера у колишніх буровугільних котлованах післягірничих ландшафтів Німеччини.

Предмет дослідження - методи і засоби визначення особливостей водогосподарської рекультивації буровугільних післягірничих ландшафтів Німеччини, що дасть змогу раціонально використовувати рудникові вод із діючих буровугільних кар'єрів для забезпечення швидкого затоплення котлованів придатною для купання водою.

Мета дослідження - аналіз фактичної інформації про особливості водогосподарської рекультивації у районах, які до початку видобутку бурого вугілля у промислових масштабах, мали невелику кількість поверхневих водних об'єктів та ії важливості для покращення екологічного й економічного потенціалу післягірничих територій.

Завдання дослідження полягало в отриманні даних про новостворені штучні водойми на місці буровугільних розробок відкритого типу, їх технічну безпеку та особливе екологічне й господарське значення.

Наукова новизна отриманих результатів дослідження полягає в тому, що вперше розроблено методику, яка дає змогу на підставі аналізу робіт із водогосподарської рекультивації ландшафтів після добування бурого вугілля у Німеччині визначити екологічні ризики, насамперед усунення наслідків підняття грунтових вод, недостатнього обслуговування водойм, потреби регулярного протиповіневого захисту, неналежної якості води, реорганізації тимчасових водойм та геотехнічної безпеки бортів кар'єрів і схилів відвалів.

Практична значущість отриманих результатів дослідження полягає в тому, що їх можна використати у практиці планування рекультиваційних робіт на післягірничих ландшафтах України для забезпечення охорони природи, а також раціонального користування ре- сурсами порушених земель на засадах, максимально наближених до природних.

Аналіз літературних джерел. Центральнонімецький буровугільний район має давні свідчення гірничої діяльності в Німеччині $[1,2,4,5,6]$. У XVII-xVIII ст. селяни добували буре вугілля для домашніх потреб у сезонних копанках. Із середини XIX ст. значення бурого вугілля зросло через нестачу та подорожчання дров у поєднанні з одночасним збільшенням потреби у паровій енергії, як джерела силового приводу, та для залізниці, як ефективного засобу транспорту. Буре вугілля прискорило процес індустріалізації. Це супроводжувалося технічними нововведеннями (перший брикетний прес у світі в 1858 р. в Аммендорфі поблизу Галле, напівкоксування лігніту з 1860 р., електростанції з 1910 р., синтез аміаку та пального 31915 р.) [2]. У технологічний розвиток завжди вкладався політичний контекст, оскільки відбувалося виробництво "важливих для війни" продуктів як у Першу, так і в Другу світові війни. Ситуація не змінилася після 1945 р. [1, 2, 6, 10]. Східна Нiмеччина не мала альтернативи у використанні сировини для виробництва електроенергії, карбохімії й теплопостачання $[2,6]$. Буровугільна промисловість забезпечувала зайнятість населення та виробництво продукції $[1,2$, $3,5,6,10,12]$, спричиняючи забруднення навколишнього середовища на кожному етапі технологічного циклу (рис. 1).

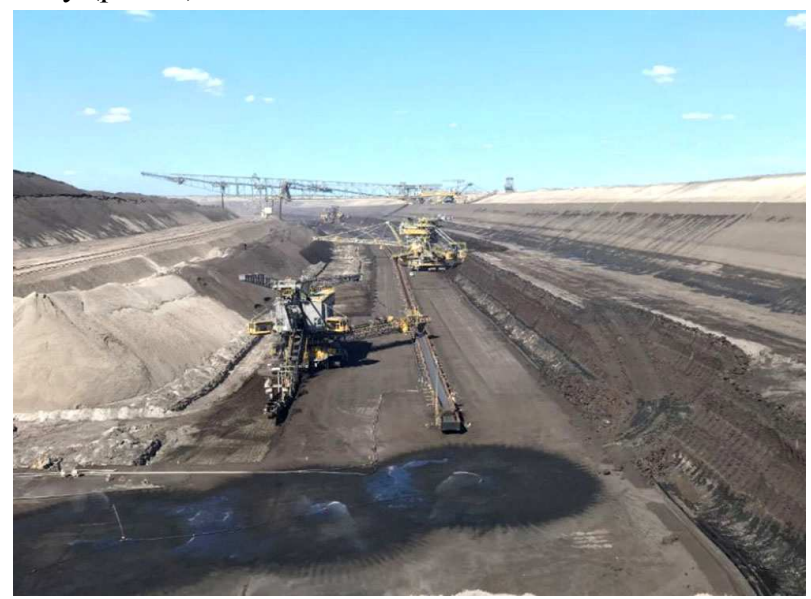

Рис. 1. Добування бурого вугілля у Лаузіцькому родовищі

Видобування бурого вугілля поверхневим способом здійснювали у трьох великих буровугільних родовищах Німеччини (табл. 1, рис. 2).

Ситуація змінилася після політичних подій у 19891990 рр. Промислове виробництво впродовж 19891992 рр. знизилося на 75 \% [10]. Ринок енергії став відкритим для газу та нафти. Екологічні закони Федеральної республіки Німеччини почали застосовувати 3 1 липня 1990 р. і регулювали діяльність електростанцій. Нові економічні та екологічні умови 1990 р. показали, що добування бурого вугілля у попередніх вимірах і конфігураціях використання не матиме майбутнього [1, $2,5,10,12]$. У Центральній Німеччині видобуток лігніту стрімко знизився. 3 близько 20 родовищ відкритого типу залишилися три. Карбонізація бурого вугілля завершилася у 1990 р., а процес брикетування - у 2003 р. Жодна з великих електростанцій, що працювали на спалюванні бурого вугілля, не виявилася здатною до модернізації, тому добування здійснювали у значно менших обсягах на ретельно оновленій технологічній осноBi [2]. 
Табл. 1. Порівняння Рейнського, Центральнонімецького та Лаузіцького буровугільних родовищ [2]

\begin{tabular}{|c|c|c|c|}
\hline \multirow{2}{*}{ Критерій } & \multicolumn{3}{|c|}{ Родовище } \\
\hline & Рейнське & Центральнонімецьке & Лаузіцьке \\
\hline Геологічні запаси бурого вугілля & 51,0 млрд т & 10,0 млрд т & 11,6 млрд т \\
\hline Господарсько доступні запаси & 31,0 млрд т & 2,0 млрд т & 3,1 млрд т \\
\hline Затверджені / розроблені поля & 2,8 млрд т & 0,4 млрд т & 0,9 млрд т \\
\hline Загальний видобуток бурого вугілля & 8,3 млрд т & 8,7 млрд т & 8,3 млрд т \\
\hline Загальна кількість порожньої породи & 24 млрд м ${ }^{3}$ & 20 млрд м ${ }^{3}$ & 37 млрд м ${ }^{3}$ \\
\hline Типова глибина кар'єрів & $200>400 \mathrm{M}$ & $50-130 \mathrm{M}$ & $50-140 \mathrm{M}$ \\
\hline Співвідношення породи до вугілля & $4,73 \mathrm{M}^{3} \cdot \mathrm{T}^{-1}$ & $2,87 \mathrm{M}^{3} \cdot \mathrm{T}^{-1}$ & $5,98 \mathrm{M}^{3} \cdot \mathrm{T}^{-1}$ \\
\hline Поточний рівень добування & 90,5 млн т & 17,7 млн т & 62,3 млн т \\
\hline Найвищий рівень добування (рік) & 120,6 млн т (1984) & 145,5 млн т (1963) & 200,3 млн т (1988) \\
\hline Переселені жителі & 44000 & 53000 & 29000 \\
\hline Співробітники & 8961 & 2414 & 8278 \\
\hline Співробітники (максимум, рік) & $26390(1958)$ & $64447(1958)$ & $79193(1985)$ \\
\hline Загальне землекористування & $327,5 \mathrm{\kappa m}^{2}$ & 486,2 км $^{2}$ & $879,1 \mathrm{\kappa м}^{2}$ \\
\hline Частка відновлених земель & $70,6 \%$ & $74,7 \%$ & $65,1 \%$ \\
\hline Об'єм затоплюваного котловану & 6,6-7,0 млрд м ${ }^{3}$ & 3,5 млрд м ${ }^{3}$ & 4,0 млрд м ${ }^{3}$ \\
\hline Площа зниження грунтових вод (максимум) & 3120 км² $^{2}(1998)$ & $1100 \mathrm{Kм}^{2}(1990)$ & $2100 \mathrm{Kм}^{2}(1990)$ \\
\hline
\end{tabular}

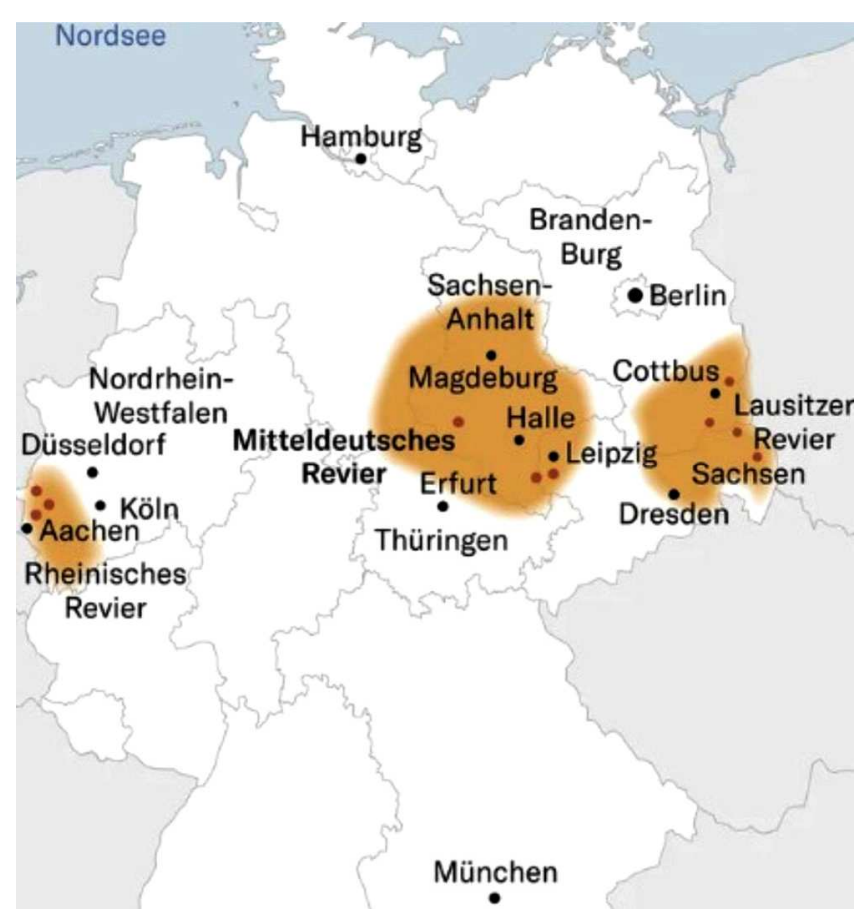

Рис. 2. Буровугільні родовища Німеччини [3]

У Центральній Німеччині побудовано електростанції в Ліппендорфі (Саксонія, 1840 МВт, введення в експлуатацію у 2000 р.) та Шкопау (Саксонія-Ангальт, 1000 МВт, введення в експлуатацію у 1996 р.). Обидва підприємства були побудовані на промислових пустищах, мають ефективність понад $40 \%$ та постачають населені пункти за допомогою комбінованого тепла та електроенергії (Ліппендорф із покриттям приблизно $70 \%$ потреб у централізованому опаленні міста Лейпциг, Шкопау із забезпеченням технологічної парою для однойменної хімічно-промислової місцевості). Функціонування електростанції розраховували на 40 років. Інвестиції для Ліппендорфа становили 2,2 млрд євро [2]. Зважаючи на цілі щодо захисту клімату, в Німеччині триває інтенсивна дискусія щодо перспектив розвитку добування бурого вугілля $[3,5]$. Політичні позиції поділяються між крайніми сценаріями виходу (до 2025 р.) та "впорядкованим припиненням" виробництва електроенергії на підставі лігніту (у Центральній Німеччині до 2040 р., Райнланд та Лаузіц до 2050 р.) [2].
Матеріали і методи дослідження полягали в аналітичному опрацюванні результатів досліджень науковців та природоохоронної документації гірничої компанії Лаузіц й Центральної Німеччини. Доповнення й актуалізацію даних здійснювали шляхом роботи із онлайн-базами.

\section{Результати дослідження та їх обговорення}

На підставі використання для відтворення порушеної території основних озер, річок, каналів та шлюзів асоціацією регіонального планування розроблено проект рекультивації "Центральнонімецький озерний пейзаж" [2, 7, 8, 9].

Район Лейпциг-Галле-Дессау до початку видобутку бурого вугілля у промислових масштабах мав невелику кількість поверхневих водних об'єктів. Це були водойми, утворені вилуговуванням солі, природні озера (озера Менсфельд), рибні ставки (ставки Хазельбахера та Регізера) та невеликі озера, як результат видобутку піску, гравію, глини, глини або твердих порід. Внаслідок появи більших кар'єрів із добування бурого вугілля перші озера виникли близько 1920 р. (райони Зшорневіц та Борна-Мезельвіц), які із 1950-х років використовували як водосховища.

Унаслідок закриття численних буровугільних кар'єрів із 1990 р. та поступового припинення відкачування грунтових вод, пов'язаних з видобутком, на тери-

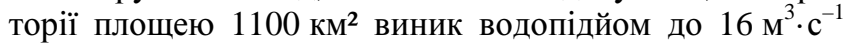
[2]. Це зумовило у багатьох місцях сприятливі умови для створення великих кар'єрних озер. Після надійного укріплення бортів кар'єрів їх затоплення було раціональним напрямом водогосподарської рекультивації, перевагою якого є відсутність потреби догляду. У районі нових озер Лейпцига для забезпечення швидкого затоплення котлованів придатною для купання водою використано рудникові води, що надходили із діючих буровугільних кар'єрів Профен та Ферайнігтес Шлейнхайн (закрито у 2009 р.) через трубопровідну систему завдовжки 74 км $[2,7,8,9,11]$. Ця практика застосовувалася у 1998-2018 рр. Вона означає зв'язок між діючим вуглевидобутком та рекультивацією для найкращих результатів (рис. 3).

Котловани інших недіючих буровугільних кар'єрів заповнювалися водами із місцевих річок: у Гейзелталь - із Заале, у Біттерфельд-Графенгайнічен - із Мулде, у Лейпциг - із Вайссельстер, у Ашерслебен-Нахтерштедт - із Сельке. Наповнення водою завдяки підняттю грун- 
тових вод $є$ винятками (озера Паупіцчер і Боквітцер). Для регулювання кінцевого рівня води із заданими діапазонами коливань більшість озер були обладнані з'єднувальними спорудами із місцевими водоймами.

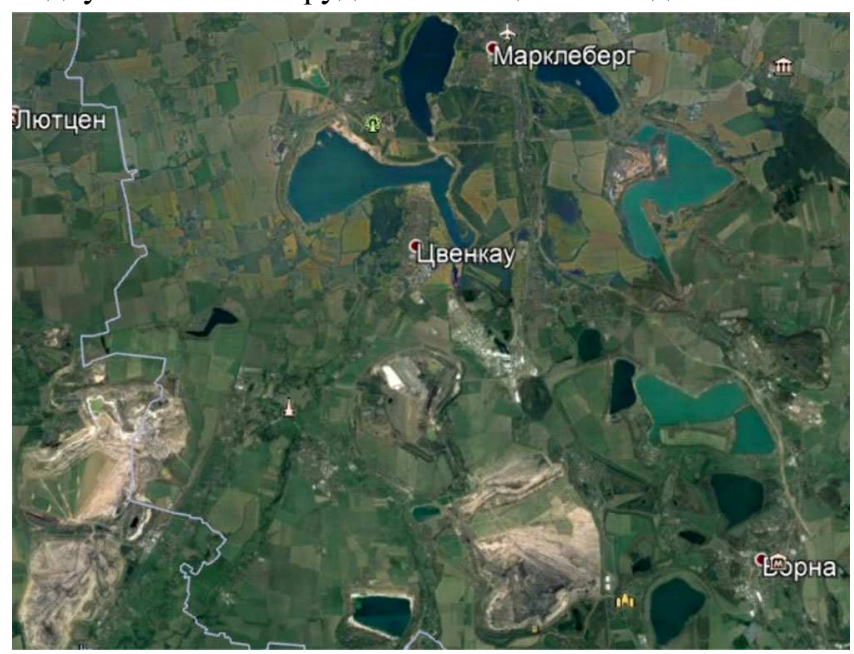

Рис. 3. Штучні озера поблизу Лейпціга (Geobasis-DE/BKG)

Після 2050 р. новий озерний ландшафт охоплювати-

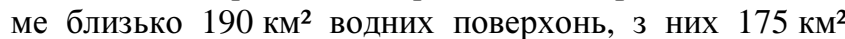

об'ємом 3,8 км$^{3}$ як відкриті гірничі озера $[2,11]$. Для регіону Центральної Німеччини очікується широкий спектр їх використання для дозвілля і відпочинку (пляжі для купання, пристані, наметові майданчики, регатні маршрути, дайвінг-центри тощо), природи та ландшафту (нові біотопи, наприклад, Паупіцчер, Кансдорфер та Зехауер) і водосховищ (протиповеневий захист, озеро Цвенкауер). Озера Гейзельтальзеє та Гейцше в перспективі займуть позиції 17 і 33 серед найбільших озер Нiмеччини (табл. 2).

Незалежно від успіхів рекультиваційних робіт, вирішення потребують складні завдання, пов'язані з водою [2]:

- наслідки підняття грунтових вод, особливо в забудованих районах, які впродовж десятиліть зазнавали осідання поверхні внаслідок гірничих робіт, через недоліки будівництва, недостатнс обслуговування водойм, зменшення забору грунтових вод та екстремальні погодні умови, посилюються;

- протиповіневий захист після повеней у серпні 2002 р. та червні 2014 р. показав високу водозатримувальну здатність буровугільних кар'єрів (Цвенкауер Зеє) та одночасно постійну готовність до активного реагування (Гойцше поблизу Біттерфельда);

- проблема якості води через надходження заліза переважно зі старих звалищ, а також його окислення та потребу запобігання надходженню сульфатів у кар'єрні озера;

Табл. 2. Найбільші озера Німеччини із класифікацією новоутворених кар'єрних озер [2]

\begin{tabular}{|c|c|c|c|c|c|}
\hline Клас & Озеро/кар'єрне озеро (регіон) & Площа, км² & Глибина, м & Об'єм, млн м ${ }^{3}$ & Завершення, рік \\
\hline 1 & Боденське озеро (Альпійські передгір'я) & 538,5 & 252 & 48465 & - \\
\hline 2 & Мюріц (Мекленбург) & 110,3 & 31 & 662 & - \\
\hline 3 & Кімзее (Альпійські передгір'я) & 82,0 & 73 & 2132 & - \\
\hline 4 & Шверинер Зеє (Мекленбург) & 60,6 & 51 & 787 & - \\
\hline 5 & Штарнбергер Зеє (Альпійські передгір'я) & 57,2 & 128 & 3089 & - \\
\hline 6 & Аммерзее (Альпійські передгір'я) & 46,6 & 81 & 1771 & - \\
\hline 7 & Плауер Зеє (Мекленбург) & 38,0 & 24 & 304 & - \\
\hline 8 & Хамбахер Зеє (Рейнське родовище) & 37,5 & 450 & 4600 & $2050+$ \\
\hline 9 & Куммеровер Зеє (Мекленбург) & 32,2 & 26 & 258 & - \\
\hline 10 & Нохтенер Зеє (Лаузіцьке родовище) & 31,0 & 90 & 650 & $2050+$ \\
\hline 11 & Штайнхудер Мер (Нижня Саксонія) & 29,4 & 3 & 59 & - \\
\hline 12 & Гросер Пльонер Зеє (озерна рівнина Гольштейн) & 29,0 & 60 & 406 & - \\
\hline 13 & Шаальзеє (Мекленбург) & 23,3 & 72 & 396 & - \\
\hline 14 & Гарцвайлер Зеє (Рейнське родовище) & 23,0 & 190 & 2000 & $2080+$ \\
\hline 15 & Селентер Зеє (озерна рівнина Гольштейн) & 22,4 & 36 & 381 & - \\
\hline 16 & Кельпінзеє (Мекленбург) & 19,9 & 28 & 80 & - \\
\hline 17 & Гейзельтальзеє (Центральнонімецьке родовище) & 18,5 & 70 & 423 & 2011 \\
\hline 18 & Коттбузер Зеє (Лаузіцьке родовище) & 18,4 & 45 & 130 & 2025 \\
\hline 19 & Толлензеє (Мекленбург) & 17,8 & 33 & 303 & - \\
\hline 20 & Вальхензеє (Альпійські передгір'я) & 16,3 & 190 & 1320 & - \\
\hline 25 & Зедлітцер Зеє (Лаузіцьке родовище) & 14,1 & 27 & 210 & 2017 \\
\hline 28 & Шармютцельзеє (Бранденбург) & 13,8 & 29 & 124 & - \\
\hline 32 & Гейцшезеє (Центральнонімецьке родовище) & 13,5 & 75 & 207 & 2002 \\
\hline 33 & Сенфтенбергер Зеє (Лаузіцьке родовище) & 13,0 & 25 & 80 & 1972 \\
\hline 34 & Бервальдер Зеє (Лаузіцьке родовище) & 13,0 & 58 & 173 & 2009 \\
\hline 39 & Інденер Зеє (Рейнське родовище) & 11,2 & 280 & 700 & 2060 \\
\hline 40 & Парштейнер Зеє (Бранденбург) & 11,0 & 30 & 110 & - \\
\hline 41 & Партвіц Зеє (Лаузіцьке родовище) & 11,0 & 41 & 134 & 2014 \\
\hline 44 & Водосховище Лоза II (Лаузіцьке родовище) & 10,8 & 46 & 97 & 2015 \\
\hline 48 & Цвенкауер Зеє (Центральнонімецьке родовище) & 9,6 & 49 & 176 & 2015 \\
\hline 49 & Берздорфер Зеє (Lausitzer Revier) & 9,7 & 70 & 333 & 2013 \\
\hline 51 & Домсенер Зеє (Центральнонімецьке родовище) & 9,2 & 82 & 253 & 2046 \\
\hline 52 & Водосховище Блейлох (Тюрингія) & 9,2 & 59 & 215 & - \\
\hline 55 & Тегернзеє (Альпійські передгір'я) & 8,9 & 72 & 400 & - \\
\hline 60 & Гроітцшер Зеє (Центральнонімецьке родовище) & 8,4 & 75 & 350 & 2050 \\
\hline 63 & Шверцауер Зеє (Центральнонімецьке родовище) & 8,1 & 78 & 213 & 2036 \\
\hline 64 & Вербелінзеє (Бранденбург) & 7,9 & 60 & 350 & - \\
\hline 65 & Гросер Мюгельзеє (Берлін) & 7,7 & 8 & 36 & - \\
\hline 71 & Стермтхалер Зеє (Центральнонімецьке родовище) & 7,3 & 52 & 157 & 2013 \\
\hline 74 & Перезер Зеє (Центральнонімецьке родовище) & 7,0 & 41 & 141 & 2051 \\
\hline
\end{tabular}


- реорганізація водойм у районах змінених вугледобуванням річок, каналізовані ділянки яких не відповідають чинним екологічним стандартам (Рамкова директива щодо водних ресурсів (С) та не були побудовані для тривалої експлуатації;

- геотехнічна безпека бортів кар'єрів і схилів відвалів, яка набула особливого значення після кількох потужних зсувів (Нахтерштедт, 2009 р.).

Окремі питання, пов'язані із передачею майна, утриманням водойм, муніципальними правилами користування, судноплавством, будівництвом на воді, можливостями розвитку для тренд-спорту (наприклад, катання на водних лижах), а також догляд за ними (наприклад, окислення) потребують подальших політичних, юридичних, планувальних і наукових рекомендацій та рішень.

\section{Висновки}

Водогосподарський напрям рекультивації відпрацьованих буровугільних кар'єрів Німеччини є ефективним i забезпечує їх повернення у національногосподарське користування у порівняно короткі терміни. Водночас необхідними є роботи із регулярного підтримування штучно створеної техноекосистеми та обслуговування штучних водойм. Це потрібно фіксувати у регіональних планах рекультивації, які мають поточне оновлення. Спілкування 3 населенням є ключовою умовою успіху, оскільки більшість проблем є наслідком цього дефіциту. Основна увага повинна бути зосереджена на конструктивній співпраці та прагненні найкращого вирішення проблем між просторовим плануванням та напрацюваннями спеціалістів.

\section{References}

1. Berkner, A. (2018). Braunkohlenplanung. In: Akademie für Raumforschung und Landesplanung. Hrsg, Handwörterbuch der Stadt- und Raumentwicklung. Hannover.
2. Berkner, A. (2019). Planungen zur Wiedernutzbarmachung und zur Regionalentwicklung. Erfahrungen und Handlungsschwerpunkte für die Region Leipzig-Westsachsen. In: Rekultivierung und Revitalisierung der Bergbaufolgelandschaften in Polen und Deutschland: Planungs-, Natur und Kulturvoraussetzungen, 21-36

3. Braunkohleplanung der Länder an nationale Klimaschutzziele anpassen. Retrieved from: https://www.agora-energiewende.de.

4. DEBRIV - Deutscher Braunkohlen-Industrie-Verein: Jahresbericht. (2016). Hrsg, DEBRIV. Berlin/Koln.

5. Die Ressource Braunkohle. Retrieved from: http://braunkohlewissen.de/braunkohle-wissen-03/; Energiestudie. Retrieved from: http://www.bgr.bund.de/DE/Themen/Energie/Downloads.

6. Drebenstedt, C., \& Kuyumcu, M. (2014). Braunkohlesanierung: Grundlagen, Geotechnik, Wasserwirtschaft, Brachflächen, Rekultivierung, Vermarktung. Hrsg. Springer Verlag. Berlin/Heidelberg.

7. LMBV mbH - Lausitzer und Mitteldeutsche Bergbau-Verwaltungsgesellschaft. (2017a). Gewässerverbindung Zwenkauer See - Cospudener See (Harthkanal) im Kurs 1 des Touristischen Gewässerverbundes im Leipziger Neuseenland. Hrsg, LMBV $\mathrm{mbH}$. Senftenberg.

8. LMBV mbH - Lausitzer und Mitteldeutsche Bergbau-Verwaltungsgesellschaft. (2017b). Sicherung der Gewässergüte in Bergbaufolgeseen. Information zur Beschaffenheit von ausgewählten Bergbaufolgeseen im Südraum Leipzig. Hrsg.- LMBV $\mathrm{mbH}$. Senftenberg.

9. LMBV mbH - Lausitzer und Mitteldeutsche Bergbau-Verwaltungsgesellschaft. (2016). LMBV Flutungs-, Wasserbehandlungsund Nachsorgekonzept Mitteldeutschland. Gestaltung von Gewässersystemen in den Bergbaufolgelandschaften Mitteldeutschlands. Hrsg, LMBV mbH. Senftenberg.

10. Riesner,W. (2009). Die Energiewirtschaft in Ostdeutschland - Ein Rückblick auf die letzten 60 Jahre. $e B W K, 61(12), 1-11$

11. RPV L-WS - Regionaler Planungsverband Leipzig-Westsachsen. (2014). Anpassungsstrategien an den Klimawandel für den Südraum Leipzig. KlimaMORO Phase II. Hrsg, RPV L-WS. Leipzig.

12. Statistik der Kohlenwirtschaft E. V. (2019). Braunkohlenförderung. Retrieved from: https://kohlenstatistik.de/

U. B. Bashutska

Ukrainian National Forestry University, Lviv, Ukraine

\section{WATER RECLAMATION OF LANDS OF GERMANY DISTURBED BY LIGNITE MINING}

The mining activities of humanity greatly change the natural landscape. The reclamation of post-mining areas is the responsibility of mining companies. This is enshrined in law of each country. Landscape functions must be restored. This will ensure the maintenance of the natural balance and subsequent economic use of the territory as quarries and dumps are inhabited by plant and animal species. It means integrating former lignite mining lines into local and regional business networks. At the same time, social and cultural functions need to be reorganized and developed. A comparison of brown coal mining by a surface method in three large lignite deposits in Germany according to the main criteria is made. The reclamation project "Central German Lake Landscape" is analyzed. According to the project, the disturbed territory of the main lakes, rivers, canals, and locks should be used to recreate them. The connection between the closure of lignite quarries, the cessation of groundwater pumping, and the subsequent rise is given. Such a rise is a favourable factor for the creation of large artificial reservoirs. The rational use of mine waters from existing lignite quarries is analyzed. This will ensure rapid flooding of the ditches with bathing water. This practice has been used for the last twenty years. It reflects the correlation between current coal mining and reclamation for the best results. The location of newly formed quarry lakes in the system of the largest lakes in Germany is shown. The range of their use for leisure and recreation, nature protection and the landscape are indicated. Ecological risks are possible by water reclamation of post-mining landscapes. Many issues need to be addressed. Among them are as follows: eliminating the effects of rising groundwater, insufficient maintenance of reservoirs, necessity to regularly take care of flood protection, a problem of water quality due to the influx of iron and its oxidation, a reorganization of reservoirs that were not built for long-term operation, and the geotechnical safety of open-pit mining and dumps. Complex tasks of water management are noted. They still need a solution to ensure ecological balance.

Keywords: brown coal deposit; mining; restoration; landscape; open-pit mining; lignite; artificial reservoir. 